\title{
Franchising in Residential Brokerage
}

Authors

John D. Benjamin, Peter Chinloy, G. Donald Jud and Daniel T. Winkler

Abstract

This paper explores the profitability of real estate franchises. The database for the study consists of observations from the National Association of Realtors ${ }^{\circledR} 2001$ survey of real estate brokerage firms. Franchises are found to generate additional revenue for franchisees. However, net margins defined as the difference between revenues received and expenses paid (including franchise royalties) are lower for firms with franchises. The findings indicate that franchisors appear to extract the excess rents from the franchisee.

\section{Introduction}

Franchising is widespread in the real estate industry, particularly in the hotel and residential brokerage sectors. According to the National Association of Realtors ${ }^{\circledR}$ (see www.realtors.org), there are over I million Realtors ${ }^{\circledR}$ of which approximately one-third work for franchised residential brokerage firms. Previous research by Lewis and Anderson (1999) reveals that franchise-affiliated firms have lower costs than independent brokerage firm. Anderson. Lewis and Zumpano (2000) show that franchised firms are more efficient than their non-franchised counterparts, but they further report that franchise affiliates are not necessarily more profitable. ${ }^{1}$ The findings presented in this paper provide further insight into the relationship between franchisors and their affiliates. $^{2}$

In exchange for receiving a proportion of revenue, such as the $8 \%$ charged by Cendant to Century 21 franchisees, the franchisor provides stipulated benefits by contract to the franchisee. ${ }^{3}$ A franchise offers a well-known brand name that signals information about the quality of the firm (including reliability) to new and existing clientele. Additional benefits can include marketing, training, accounting services, etc. ${ }^{4}$ Unless the franchisor controls specific customer traffic, such as a hotel reservation system, the services sold by the franchisor are general and common to all franchisees.

This paper is organized into six sections. The following section discusses prior research on franchising, both in the real estate industry and in general. Following this overview, a model of firm profitability is developed, to describe the relationship between franchise fees and expected revenue, profit and net margin.

Benjamin, J. D., Chinloy, P., Jud, G. D., and D. T. Winkler. "Franchising in Residential Brokerage," Journal of Real Estate Research, vol. 28, no. 1, 2006, pp. 61-70.

Made available courtesy of the American Real Estate Society. 
Next, the empirical model and sample data are discussed. Empirical findings and concluding remarks are presented in the last two sections.

\section{Franchising and Residential Brokerage}

Past studies support the hypothesis that franchise affiliates have higher gross revenues that allow them to pay positive fees to the franchisor. For example, Jud, Rogers and Crellin (1994) show that franchise affiliation results in a 9\% increase in net revenue. ${ }^{5}$ These studies ignore whether franchises have greater profitability. Even though there is a difference in sales performance across franchisees, and within the same unit over time, the fees levied by franchisors are relatively constant and not performance-based (Lafontaine and Shaw, 1999).

Another area of academic study of franchising is marketplace signaling. Signaling information about the quality of the franchisee is not available initially, but becomes observed over time (Gallini and Lutz, 1992). Franchisees that survive have better reputations and, therefore, should qualify for lower fees (Mathewson and Winter, 1985). Lafontaine and Shaw (1999) indicate that information differences across franchisees are small and that imposing a plethora of separate fees leads to management costs. They find that the royalty, or percentage fee, and the fixed franchise fee are not negatively correlated. ${ }^{6}$

\section{A Model of Residential Real Estate Franchising}

In the conventional industrial organization analysis, franchising is a method of extracting effort by reallocating incentives. The royalty is the percentage payment from income to the franchisor, and the franchise fee is the fixed up-front cost. Let $R$ be the percentage of revenue paid as the royalty and $F$ be the franchise fee. The amount of broker labor input for a non-franchised firm is $B_{\mathrm{N}}$ while $W_{\mathrm{N}}$ is the wage, or dollar split of the commission revenue paid to sales agents. With no franchise membership, the profit for the firm is $P=Y\left(K_{N}, B_{N}\right)-W_{N} B_{N}$ where $K_{N}$ represents fixed inputs and $\mathrm{Y}$ is the firm's revenue function.

In franchising. as with any business organization, labor input and effort are contingent on the form of the organization. If only an employee, a manager would put in less input and effort than would be the case if awarded a share of the profit. If the same firm is organized as a franchise, then maximizing profit of the franchisor subject to a profit-making condition of the franchisee yields: $P^{\prime}=$ $(1-R) Y^{\prime}(K, B)-F-W B$. Here $\mathrm{W}$ is the compensation for all employees except the brokerage firm owner (franchisee). In real estate markets, the franchise fee $(F)$ is usually negligible, but $R$ can be substantial. Real estate brokerage firms are frequently liquidity-constrained with limited resources to pay a fixed fee.

There are numerous real estate brokerage firms, and most brokerage firms have the opportunity to join a franchise. However, a firm will only join a franchise if it is profitable, so marginal revenue must at least equal marginal cost. But in 
equilibrium, all brokerage firms must earn normal profits. Franchise firms may offer more market appeal to customers than non-franchise firms because they offer more name recognition (a positive signal) and perhaps reduce uncertainty for customers. Franchise firms have higher revenues that allow franchisees to recover their fixed franchise fees $(F)$ and royalties $\left(R Y^{\prime}\right)$. However, if franchisors extract the excess economic rent from their franchisees, the profits of both franchise and non-franchise firms should be the same.' Setting the profit equations equal $(P=$ $P^{\prime}$ ), the equilibrium level of revenues $\left(\mathrm{Y}^{*}\right)$ of franchisees who recover expenses $F$ and RY occurs at labor input $B^{*}$, wage level $\mathrm{W}^{*}$ and capital $K^{*}$ :

$$
Y^{*}\left(K^{*}, B^{*}\right)=\frac{Y\left(K_{N}, B_{N}\right)}{1-R}+\frac{\left(W^{*} B^{*}-W_{N} B_{N}\right)+F}{1-R} .
$$

Expressing Equation (1) as a percentage change in revenue from the base of nonfranchisee revenues to achieve equilibrium profits, $\left(\% \Delta Y^{*}\right)$, and substituting the increase in franchising costs as a percentage of non-franchising firm revenues, $Z=\frac{\left(W^{*} B^{*}-W_{N} B_{N}\right)+F}{Y\left(K_{N}, B_{N}\right)}$, the equilibrium percentage change in revenues is:

$$
\% \Delta Y^{*}=\frac{1+Z}{1-R}
$$

where $\% \Delta Y^{*}>0$, as $Z>0$ and $0<R<1$.

While revenues are expected to increase with franchising, the profit margin declines assuming that the franchisor captures all excess rents. The difference is in the profit margin: $\Delta M$ is the franchisee profit margin, $\frac{P^{\prime}}{Y^{\prime}(K, B)}$, minus the nonfranchisee profit margin, $\frac{P}{Y\left(K_{N}, B_{N}\right)}$. Substituting for $P^{\prime}$ and $P$ and solving for $\Delta M$, the resulting relationship can be simplified as:

$$
\Delta M=-R-\left[\frac{F+W B}{Y^{\prime}(K, B)}-\frac{W_{N} B_{N}}{Y\left(K_{N}, B_{N}\right)}\right]
$$

In words, the difference in the franchise profit margin $\Delta M$ (or incremental profit margin) will only become positive if the franchise royalty $R$ plus the relative cost of franchise labor $W B$ and the fixed franchise fee $F$ (as a percentage of franchise revenue) are less than the non-franchisee labor $\operatorname{cost} W_{N} B_{N}$ (as a percentage of non- 
franchise revenues). It is expected that the franchisor captures the excess rents through $F$ and $R$, and also, that the franchisee must hire additional labor to achieve the higher revenue level; therefore, $\Delta M<0$. If the franchise fee $F$ is low then the margin $\Delta M$ could still be negative if $R$ is sufficiently high. Thus, in real estate brokerage, a franchisor could set a low franchise fee $F$ without altering incentives.

\section{Data}

The sample is from a national survey of residential brokerage firms about their financial performance, conducted by the National Association of Realtors ${ }^{\circledR}$. The survey was conducted on 9,321 firms in Spring 2001. The response rate was 2,792 useable surveys or $30 \%$.' If more than $50 \%$ of a respondent's business was from commercial brokerage, the survey was removed from the sample in order to obtain a sample of real estate firms that focus primarily on residential real estate. Missing responses to key variables and the $50 \%$ residential brokerage constraint reduced the sample to 1,792 useable observations.

Exhibit 1 presents the descriptive statistics for the 1,792 observations. There is a distribution between franchised and non-franchised firms. Of the sample, $26 \%$ are franchised with the remaining $74 \%$ non-franchised. Of all firms, $98 \%$ are members of a referral or relocation network. The average firm makes a net margin of $18.6 \%$ in profit on its sales, and it has been in business for 21 years. This average business length creates a time to establish local information networks. The sample is distributed across the country: $33 \%$ in the South, $23 \%$ in the Midwest, $26 \%$ in the West and $18 \%$ in the East. Of the sample, $60 \%$ have only one office and $56 \%$ of the firms have 10 or fewer brokers or agents.

\section{Empirical Results}

Exhibit 2 presents empirical models of brokerage firm total revenue, net income, and net margin, where franchise affiliation is one of the independent variables. The independent variables in the models also include the number of relocation services subscribed to by the firm (Reloc), the age of the firm (Age), various proxies for the size of firm (Oneoff, Mfirm and Lfirm), the number of third-party websites on which the firm's listings appear (Numbwehs) and regional variables.

Each of the three financial performance models (revenue, net income and net margin) is statistically significant at the $1 \%$ level or better, with model F-values ranging from 47.93 in the total revenue model to 16.58 in the net income model. The adjusted $R^{2}$ varies from .25 in the total margin model to .13 in the net income model.

All of the dependent variables appear in logarithmic form, and these regressions are estimated using weighted least squares to correct for sample heteroscedasticity. ${ }^{9}$ The weights used in this procedure are the sample weights 
Exhibit 1 | Summary Statistics

\begin{tabular}{|c|c|c|c|c|}
\hline Variable & Description & $N$ & Mean & Std. Dev. \\
\hline Revenue $(\$ \mathrm{~m})$ & Gross revenue & 1,792 & 29.33 & 305.51 \\
\hline Lrev & Natural log, gross revenue & 1,792 & 14.05 & 2.29 \\
\hline Net Income $(\$ \mathrm{~m})$ & Annual net operating income & 1,143 & 1.68 & 11.83 \\
\hline Linc & Natural log, net operating income & 1,143 & 11.78 & 2.19 \\
\hline Net Margin (\%) & Net margin on gross revenue, percentage & 1,143 & 18.56 & 19.07 \\
\hline Lnetmargin & Natural log, net margin & 1,143 & 2.43 & 1.05 \\
\hline Reloc & One if member of a relocation network & 1,792 & 0.98 & 0.13 \\
\hline Fran & One if firm is a franchisee & 1,792 & 0.26 & 0.44 \\
\hline Age & Firm age in number of years & 1,792 & 20.91 & 17.78 \\
\hline Oneoff & One if firm has only one office & 1,792 & 0.60 & 0.49 \\
\hline Mfirm & Medium-sized firm, 11-200 salespersons & 1,792 & 0.39 & 0.49 \\
\hline Lfirm & Large firm, more than 200 salespersons & 1,792 & 0.05 & 0.22 \\
\hline West & One if firm is located in western U.S. & 1,792 & 0.26 & 0.44 \\
\hline South & One if firm is located in southern U.S. & 1,792 & 0.33 & 0.47 \\
\hline Midwest & One if firm is located in midwest U.S. & 1,792 & 0.23 & 0.42 \\
\hline Numbwebs & Number of third-party websites & 1,792 & 2.93 & 1.54 \\
\hline
\end{tabular}

Notes: The economic research group of the NAR sent a firm profile questionnaire during Spring 2001 to 9,321 real estate brokerage firms. Respondents returned 2,792 useable surveys, which represents a $30 \%$ response rate. To obtain a sample of only residential real estate brokerage firms, if less than $50 \%$ of a respondent's business was from residential brokerage, the observation was removed from the sample. The sample was reduced to 1,792, while only 1,143 firms responded to the Net Margin question. Net income is defined as Net Income = Net Margin * Revenue.

from the NAR survey, and they are designed to reflect the differential probability of firm and item non-response. ${ }^{10}$

The results in Exhibit 2 show that in the total revenue regression equation, the coefficient on the franchise variable $\left(b_{y}\right.$ is positive and significant at the $1 \%$ level. The increase of 0.37 for the franchise variable translates to approximately an increase of $45 \% .{ }^{11}$ Among other variables in the revenue equation, being a member of a relocation network increases sales revenue. ${ }^{12}$ The age variable results show that a firm obtains $2 \%$ more sales revenue with each year of age. The production function does not have negative returns in the realm of operations, since revenue and net income are increasing in the size of firm. The findings also indicate that number of third-party website upon which listings appear is found to be significantly and positively related to sales revenue: the interaction of this variable with relocation service, however, is negative but not statistically significant. In addition, sales revenues of firms are not related to region of the country. 
Exhibit 2 | Brokerage Firm Financial Performance

\begin{tabular}{|c|c|c|c|c|c|c|}
\hline \multirow[b]{2}{*}{ Variable } & \multicolumn{2}{|c|}{ Ln(Revenue) } & \multicolumn{2}{|c|}{ Ln(Net Income) } & \multicolumn{2}{|c|}{ Ln(Net Margin) } \\
\hline & Coeff. & t-value & Coeff. & A-value & Coeff. & t-value \\
\hline Constant & 10.38 & $30.7^{*}$ & 6.02 & $12.1^{*}$ & 0.89 & $3.7^{*}$ \\
\hline Fran & 0.37 & $3.1^{\circ}$ & 0.11 & 0.7 & -0.22 & $-2.8^{*}$ \\
\hline Reloc & 0.75 & $2.5^{* *}$ & 4.65 & $10.1^{*}$ & 2.92 & $13.0^{*}$ \\
\hline Age & 0.02 & $5.0^{*}$ & 0.01 & $2.3^{* *}$ & -0.01 & $-3.1^{*}$ \\
\hline Oneoff & -0.20 & -1.8 & -0.02 & -0.1 & 0.10 & 1.4 \\
\hline Mfirm & 1.88 & $10.5^{*}$ & 0.84 & $3.9^{*}$ & -0.89 & $-8.3^{*}$ \\
\hline Lfirm & 3.54 & $6.5^{*}$ & 3.12 & $4.2^{*}$ & -0.80 & $-2.2^{* *}$ \\
\hline Numbwebs & 0.70 & $2.8^{*}$ & 1.79 & $6.4^{*}$ & 0.86 & $6.2^{\circ}$ \\
\hline Reloc* Numbwebs & -0.36 & -1.5 & -1.72 & $-6.1^{*}$ & -1.00 & $-7.2^{*}$ \\
\hline West & 0.11 & 0.7 & 0.06 & 0.3 & 0.06 & 0.7 \\
\hline South & 0.23 & 1.6 & -0.16 & -0.8 & -0.32 & $-3.5^{*}$ \\
\hline Midwest & 0.19 & 1.2 & -0.12 & -0.6 & -0.24 & $-2.5^{* *}$ \\
\hline Adj. $R^{2}$ & & 0.23 & & 0.13 & & 0.25 \\
\hline Model F-value & & $47.93^{\circ}$ & & $16.58^{*}$ & & $36.33^{*}$ \\
\hline
\end{tabular}

Notes: For $\operatorname{Ln}($ Revenue), $N=1,792$; for $\operatorname{Ln}($ Net Income) and $\operatorname{Ln}($ Net Margin), $N=1,143$.

* Indicates significance at the .01 level, using a two-tailed test.

** Indicates significance at the .05 level, using a two-tailed test.

The net margin regression results are shown in the last column of Exhibit 2. The franchise coefficient has the expected $\beta_{\mathrm{m}}<0$, indicating lower profit margins for franchisees. The net margin coefficient in Exhibit 2 is -0.22 ; a firm with a franchise has a margin that is $19.7 \%$ lower than a firm that does not have a franchise. At the sample mean margin of $18.6 \%$ of gross revenue, a firm with a franchise has a margin of about four percentage points lower, or $14.9 \%$. The findings indicate that relocation services have a very strong positive effect on the net margin and, when evaluated in the context of firm revenue and net income, suggest that the cost of providing such services is low. The number of third-party websites upon which listings appear is strongly and positively related to net income. However, for firms with such third-party website listings, the benefit of relocation services declines substantially, as indicated by the large negative interaction coefficient. This finding supports the contention that firms that are part of a relocation network can increase their revenue, but that web impact reduces the benefit of a relocation service." Contrary to the positive age coefficient with respect to revenues, the age coefficient shows that a firm obtains $1 \%$ lower profit 
margin with each year of age. Larger firms do have smaller margins; medium and large firms have coefficient values of -0.89 and -0.80 , respectively. There are some additional regional effects, with margins being lower in the South and Midwest.

Finally, from the second column of Exhibit 2, the coefficient on the franchise variable in the net income equation is zero. This coefficient in the information differential model should be non-positive assuming that the franchisor absorbs excess rents. If the net income coefficient were statistically positive, the franchise fee plus royalty would be under-priced. The relocation service coefficient is positive and highly significant; this is consistent with the view that the cost of offering such services is relatively low. Although the magnitudes of the other coefficients differ from the sales revenue regression, the coefficient signs of the coefficients are the same for the significant variables including age, size number of third-party website listings and the interaction variable for third-party website listings and relocation service.

The use of technology, as measured by the number of third-party websites for firm listings, and the use of a relocation service are statistically significant and positive at the .01 level or better in each of the three financial performance equations. However, the negative interaction variable indicates that the benefits are somewhat less for firms that effectively use a relocation network.

\section{Conclusion}

This study examines the effect of franchising on the profitability of residential real estate brokerage firms. The findings indicate that franchisees have higher revenue consistent with potential benefits of a franchise. Such benefits can include enhanced name recognition, reduction in customer uncertainty, and assistance in marketing and training. However, net profits are not statistically significantly different between non-franchise firms and franchisees. This finding is consistent with the expectation that franchisors absorb the excess rents. Moreover, the net profit margin for franchisees is less than that of non-franchise firms.

An important implication for the potential franchisee is to consider the costbenefits of a franchise. Although the global net profit advantage for a franchise does not appear to exist, individual firms might find a franchise particularly valuable depending on the current local competition, the level of knowledge and expertise of the owners, and the characteristics of the customer base in a particular locality.

\section{Endnotes}

1. Historically academic studies focus on economies of scale or scope in real estate brokerage. Zumpano, Elder and Crellin (1993) show small economies of scale except 
with very large residential brokerage firms. Zumpano and Elder (1994) show that a balanced mix of listings and sales leads to economies of scope and minimize costs. Anderson, Fok, Zumpano and Elder (1998) find that the average brokerage firm operates close to its efficient frontier.

2. Other types of real estate relationships where there is a sharing of revenue, such as with property and asset management contracts are similar lo the franchisor-franchisee relationships studied here.

3. The Cendant fee is the sum of $6 \%$ of gross revenues for a royalty and $2 \%$ for national marketing.

4. Many residential brokerage firms use customer generating tools such as technology, extensive print media and traditional direct marketing such as mailings to gain clients. Franchised firms tend to have a greater use of technology and relocation networks, as in Sirmans and Macpherson (2001).

5. Jud. Rogers and Crellin (1994) estimate that franchise affiliation yields this average 9\% increase in net revenues after subtracting the royalties, fees and other charges associated with franchise affiliation. Other researchers provide further support for positive benefits associated with franchise affiliation. Frew and Jud (1986) find that franchise affiliation has a positive effect on brokerage firm sales and house prices, while Colwell and Marshall (1986) find that the presence of a franchise, the size of the sales force and the quantity of display advertising positively affect market share of listings and sales for brokerage firms. Richins. Black and Sirmans (1987) also show that franchise affiliation has a positive effect on market performance.

6. If both parties are risk-averse, then franchising creates a sharing of the risk (Martin, 1988). In real estate, the sharing is on revenue rather than net operating income, leading to incentives by the franchisor lo increase expenses and reduce profits of the franchisee.

7. Special thanks to the anonymous reviewer who facilitated the development of the mathematical model by providing a logical set of arguments and conditions.

8. To compensate for lower response rates to surveys. NAR sent extra surveys to largersized firms (>200 licensees) and medium-sized firms (1I-200 licenses), in order to ensure a representative response by firms. Further, responses were weighted by firm size.

9. The weighted least squares estimator is: $b W L S=\left(X^{\prime} W^{\prime} W X\right)-1 X^{\prime} W^{\prime} W y$ according to Greene (1996). In our study, let $\mathrm{W}$ be a diagonal matrix containing the sample weights $\mathrm{W}$ along the diagonal and zeros elsewhere, and let $\mathrm{y}$ and $\mathrm{X}$ be the usual matrices associated with the left- and right-hand side variables.

10. 10 NAR now recognized that their surveys have a built-in response bias because larger brokerages respond at a lower rate than smaller firms. This bias is lessened in the 2001 survey by over sampling of larger firms (including both groups of 11 to 200 agents and firms with more than 200 agents). A weigh was developed to control for possible over sampling and differing response rates.

11. The increase is estimated as $\% \Delta \mathrm{Y}^{*}=\mathrm{e} 0.37-1$ because the dummy variable, Fran, is converted from the logarithmic specification by this transformation.

12. 12 Higher gross revenues also allow the franchisee owners or principals to benefit from their increased individual commission revenues, but we are unable to calculate (given our data limitations) this added benefit.

13. As suggested by an anonymous reviewer, one explanation for these findings is that homebuyers who use relocation services have limited knowledge of a local area, do not 
invest as much time in the home search process, and are more reliant on the particular brokerage firm with relocation services. This places such firms at an advantage relative to other residential brokerage firms for this type of customer. Therefore, customers could be steered to properties offering higher revenue and profits to the brokerage firm. The presence of properties listed on the web increases information availability to the buyer, and, thereby, may decrease profits and revenues for a relocation service.

\section{References}

Anderson, R.. R. Fok, L. V. Zumpano and H. W. Elder, Measuring the Efficiency of Residential Real Estate Brokerage Firms, Journal of Real Estate Research, 1998. 16:2, 139-58.

Anderson, R., D. Lewis and L. Zumpano, Residential Real Estate Brokerage Efficiency from a Cost and Profit Perspective, Journal of Real Estate Finance and Economics, 2000, 20, 295-310.

Colwell, R F. and D. W. Marshall, Market Share in the Real Estate Brokerage Industry, Journal of the American Real Estate and Urban Economics Association, 1986, 14:4, 58399.

Frew, J. R. and G. D. Jud, The Value of a Real Estate Franchise, Journal of the American Real Estate and Urban Economics Association, 1986, 14:2, 374-83.

Gallini, N. and N. Lutz, Dual Distribution and Royalty Fees in Franchising, Journal of Law, Economics and Organization, 1992, 8, 471-501.

Greene. W. W., Econometric Analysis, Third edition, New York: MacMillan Co., 1996.

Jud, G. D., R. C. Rogers and G. E. Crellin, Franchising and Real Estate Brokerage, Journal of Real Estate Finance and Economics, 1994, 8:1, 87-93.

Lafontaine, F. and K. Shaw, The Dynamics of Franchise Contracting: Evidence from Panel Data, Journl of Political Economy, 1999, 107. 1041-81.

Lewis, D. and R. Anderson, Residenlial Real Estate Brokerage Efficiency and lhe Implications of Franchising: A Bayesian Approach, Real Estate Economics, 1999, 27:3, 543-60.

Mathewson, F. and R. Winter, The Economics of Franchise Contracts, Journal of Law and Economics, 1985, 28. 503-26.

Martin, R., Franchising and Risk Management, American Economic Review, 1988, 78, 95468.

Richins, M. L., W. C. Black and C. F. Sirmans, Strategic Orientation and Marketing Strategy: An Analysis of Residential Real Estate Brokerage Firms, Journal of Real Estate Research, 1987, 2:2. 41-54.

Sirmans, S. and D. Macpherson, Affinity Programs and the Real Estate Brokerage Industry, Journal of Real Estate Research, 22, 2001. 337-51.

Zumpano, L. V. and H. W. Elder, Economies of Scope and Density in the Market for Real Estate Brokerage Services, Journal of the American Real Estate and Urban Economics Association, 1994, 22:3, 497-513. 
Zumpano, L. V., H. W. Elder and G. E. Crellin, The Market for Residential Real Estate Brokerage Services: Costs of Production and Economies of Scale, Journal of Real Estate Finance and Economics, 1993, 6:3, 237-50.

The authors are grateful to Marion Steele, Ellen Roche, Anton Haidorfer, participants of the 2004 Mid-Year AREUEA Meeting Session on Housing and Urban Issues, and anonymous referees for their helpful comments and suggestions. They also thank the National Association of Realtors for providing access to their data.

John D. Benjamin, American University, Washington, DC 20016 or jherrj@ american.edu.

Peter Chinloy, San Deign State University, San Diego, CA 98182 or chinloy@ gmail. com.

G. Donald Jud, University of North Carolina-Greensboro, Greensboro, NC 274125001 or juddon@uncg.edu.

Daniel T Winkler; University of North Carolina-Greensboro, Greensboro, NC 274125001 ordt_winkler@uncg.edu. 